J. Clin. Chem. Clin. Biochem.

Vol. 24, 1986, pp. 405-408

(C) 1986 Walter de Gruyter \& Co. Berlin - New York

\title{
Comparison of a Within-Day Solid-Phase Immunoradiometric Assay With a Solution-Phase Radioimmunoassay for the Measurement of $\alpha$-Fetoprotein in Amniotic Fluid
}

\author{
By E. J. Coombes, N. O'Connell, A. Grinter and G. F. Batstone \\ Dept. of Chemical Pathology, Salisbury General Infirmary, Salisbury, U.K.
}

(Received July 22, 1985/February 12, 1986)

Summary: Using 231 amniotic fluid samples from a Regional Screening Service, the performance of a monoclonal antibody-based solid-phase immunoradiometric assay (IRMA) for $\alpha$-fetoprotein was compared with that of a polyclonal antiserum-based solution phase radioimmunoassay (RIA). $\alpha$-Fetoprotein values determined from these samples by the two methods were in excellent agreement $(r=0.992)$ and the diagnostic performance of the two assays was identical. However, the IRMA assay displayed a greater working range than the RIA, and in addition was more rapid to perform, allowing within-day turnaround of laboratory results.

Vergleich eines innerhalb eines Tages abgeschlossenen immunradiometrischen Festphasen-Assay mit einem in Lösung ablaufenden Radioimmunoassay zur Bestimmung von $\alpha$-Fetoprotein in Fruchtwasser

Zusammenfassung: Wir verglichen an 231 Fruchtwasserproben aus einer regionalen Vorsorgeuntersuchung die Handhabung eines immunradiometrischen Festphasenassay (IRMA) auf Grundlage eines monoklonalen Antikörpers mit der eines in Lösung ablaufenden Radioimmunassay (RIA) auf Grundlage eines polyklonalen Antiserums. Die mit beiden Methoden bestimmten Werte für $\alpha$-Fetoprotein stimmen hervorragend überein $(r=0,992)$ und die diagnostische Brauchbarkeit beider Verfahren war gleichwertig.

Der immunradiometrische Assay eröffnet jedoch einen höheren Arbeitsbereich als der Radioimmunassay und ist zusätzlich schneller durchzuführen, so daß die Ergebnisse innerhalb eines Tages vorliegen und verwendet werden können.

\section{Introduction}

A new, commercially available, solid-phase immunoradiometric assay (IRMA) for the quạntification of amniotic fluid $\alpha$-fetoprotein has been compared with a solution-phase radioimmunoassay (RIA) which has been the routine assay used by the Wessex Regional Amniotic fluid $\alpha$-fetoprotein screening laboratory for three years.

The purpose of this study was to evaluate the laboratory and clinical performance of the new IRMA, which incorporates a monoclonal antibody to $\alpha$-fetoprotein and requires only a two-hour incubation period thus permitting a within-day assay service.

\section{Materials and Methods}

$\alpha-F e t o p r o t e i n$ analyses

Amniotic fluid $\alpha$-fetoprotein (AFP) was estimated by two techniques:

IRMA (SUCROSEP') AFP IRMA, Boots-Celltech Diagnostics Limited, Slough, U.K.)

This immunoradiometric assay (IRMA) was performed using the manufacturer's recommended protocol: $\alpha$-fetoprotein standard or unknown sample $(50 \mu \mathrm{l})$ is incubated for two hours at room temperature $\left(15-30^{\circ} \mathrm{C}\right)$ with ${ }^{125}$ I-labelled monoclonal antibody to $\alpha$-fetoprotein $(100 \mu \mathrm{l})$ and solid phase anti- $\alpha$ fetoprotein immunoglobulin $(100 \mu \mathrm{l})$. Throughout this incuba-

1) SUCROSEP is a trademark of Boots-Celltech Diagnostics Limited. 
tion, vigorous orbital agitation $\left(300-350 \mathrm{~min}^{-1}\right)$ is provided using an agitator (Sucroagitator, Boots-Celltech Diagnostics Limited).

At the end of the incubation phase, separation of free and bound fractions is achieved by the SUCROSEP sucrose layering non-centrifugation technique (1) using a semi-automatic instrument (Sucroseparator, Boots-Celltech Diagnostics Limited). This allows assay tubes to be rapidly separated in 20-tube batches. The overall time taken for assay separation is approximately 50 minutes.

RIA (AFP RIA, IM98 Amersham International plc, Amersham, U.K.)

This solution phase radioimmunoassay (RIA) was also performed using the manufacturer's recommended protocol except that half volume of samples and reagents were employed (the practice in our laboratory for the last 3 years). The assay procedure incorporates an $18-24$ hour incubation of $\left[{ }^{125} \Pi \alpha-\right.$ fetoprotein and antibody with $\alpha$-fetoprotein standard or sample, and separation of bound and free fractions is achieved by polyethylene glycol precipitation and centrifugation.

\section{Sample analysis}

Immediately before assay, each amniotic fluid was diluted with a serum pool of zero $a$-fetoprotein content. Normally a 1 in 200 dilution was used, but occasionally a higher dilution amniotic fluid sample was used for both immunoassays and the batches for the two techniques were commenced on the same day. Each amniotic fluid was assayed in duplicate by both techniques.

Calculation of assay results and conversion of $\alpha$ fetoprotein units

The radioactivity in all the assay tubes was counted on a multihead gamma counter (LKB 1260 multigamma II) over a 120 second period. $\alpha$-Fetoprotein values for clinical specimens from both assays were calculated for $\mathrm{kU} / \mathrm{l}$ by spline function. The following conversion factor was used for RIA results: 1 I. U. $=1.21 \mathrm{ng} \alpha$-fetoprotein $[90 \%$ confidence interval $=$ $1.02-1.43$ ] (2). These values were then corrected for the sample dilution factor and expressed as MU/1 $\alpha$-fetoprotein.

\section{Amniotic fluid samples}

231 aliquots of amniotic fluid were studied. These were taken by transabdominal amniocentesis during the second trimester of pregnancy for a variety of clinical indications. These samples were centrifuged and the supernatant either used immediately or stored at $-20^{\circ} \mathrm{C}$ until analysis.

\section{Normal pregnancies}

116 liquors from normal pregnancies were studied. For these pregnancies ultrasound examination revealed no obvious fetal abnormality. The amniotic fluid $\alpha$-fetoprotein by RIA was within normal laboratory reference limits and there was no evidence of the acetyl cholinesterase isoenzyme band on polyacrylamide gel electrophoresis $(3,4)$.

\section{Abnormal pregnancies}

109 samples were classified as 'abnormal'. These pregnancies had been terminated and the fetuses confirmed to have a severe fetal abnormality [54 open spina bifida, 32 anencephaly, 14 exomphalos, 2 gastroschisis, 7 missed abortion].

\section{'Equivocal pregnancies'}

Six samples were also included from 'equivocal pregnancies' for which the outcome of the pregnancy was a normal infant but the amniotic fluid $\alpha$-fetoprotein concentration by RIA was either borderline high or significantly elevated.

\section{Statistical methods}

$: \mathbf{1}$

Precision profile data (fig. 1) were generated using a 5-parameter curve fitting procedure provided by Boots-Celltech Diagnostics Limited. All other statistical analysis were performed by using the Minitab Statistics Package ${ }^{2}$ ).

\section{Results}

\section{Assay reproducibility}

The overall reproducibility of the IRMA was greater than that of the RIA. The intra- and inter-assay coefficients of variation (CV) for the RIA and IRMA are shown in table 1 . The greater analytical precision of the IRMA was most noteable at $\alpha$-fetoprotein concentrations above $\sim 200 \mathrm{kU} / \mathrm{l}$, and is apparent from a comparison of intra-assay precision profiles (fig. 1). Using a definition of the working range of each assay to be the $\alpha$-fetoprotein concentration associated with an intra-assay CV of $<10 \%$, the IRMA and RIA covered ranges of $3-629 \mathrm{kU} / \mathrm{l}$ and $30-363 \mathrm{kU} / 1$ respectively.

The relationship between amniotic fluid $\alpha$ fetoprotein levels measured by IRMA and RIA

As shown in figure $2, \alpha$-fetoprotein values by IRMA and RIA correlated very well $(\mathrm{n}=231, \mathrm{r}=0.992$, IRMA $=1.06$ RIA-2.35). However at $\alpha$-fetoprotein concentrations above $200 \mathrm{MU} / 1$ there appeared to be a slight divergence of results with an apparent positive bias towards the IRMA assay.

\section{Clinical performance of IRMA}

The median $\alpha$-fetoprotein concentration and range determined by IRMA for each gestational age of the normal population studied is shown in table 2 .

Figure 3 illustrates the $\alpha$-fetoprotein results obtained by IRMA for the 109 abnormal amniotic fluids in relation to the median and multiple of the median cut-off levels of the normal population (5). Using these IRMA results, all of the cases of anencephaly, exomphalos, gastroschisis or missed abortion (gestational ages between 15 and 20 weeks) were correctly classified as abnormal (greater than the respective multiple of the median (MOM) cut-off level).

2) Minitab is a trademark of MinitabInc; Pennsylvania, USA. 
Tab. 1. Assay reproducibility of RIA and IRMA (intra- and inter-assay) based on repeated analyses of control pools. (Prior to assay, samples 1 and 2 were diluted $1 / 200$, sample 3 was diluted $1 / 400$ ).

\begin{tabular}{|c|c|c|c|c|c|c|}
\hline \multirow[t]{3}{*}{ Sample } & \multicolumn{5}{|c|}{$\%$ CV } & \\
\hline & \multicolumn{2}{|c|}{ Mean $\alpha$-fetoprotein concentration (MU/l) } & \multicolumn{2}{|l|}{ Intra-assay } & \multicolumn{2}{|l|}{ Inter-assay } \\
\hline & IRMA & RIA & $\operatorname{IRMA}(n=10)$ & $\operatorname{RIA}(n=10)$ & $\operatorname{IRMA}(\mathrm{n}=10)$ & $\operatorname{RIA}(n=10)$ \\
\hline $\begin{array}{l}1 \\
2 \\
3\end{array}$ & $\begin{array}{r}22.3 \\
65.7 \\
142.9\end{array}$ & $\begin{array}{r}25.2 \\
61.9 \\
144.7\end{array}$ & $\begin{array}{l}2.7 \\
4.3 \\
3.9\end{array}$ & $\begin{array}{l}3.0 \\
5.5 \\
6.4\end{array}$ & $\begin{array}{l}3.5 \\
4.7 \\
2.6\end{array}$ & $\begin{array}{l}6.3 \\
6.3 \\
7.7\end{array}$ \\
\hline
\end{tabular}

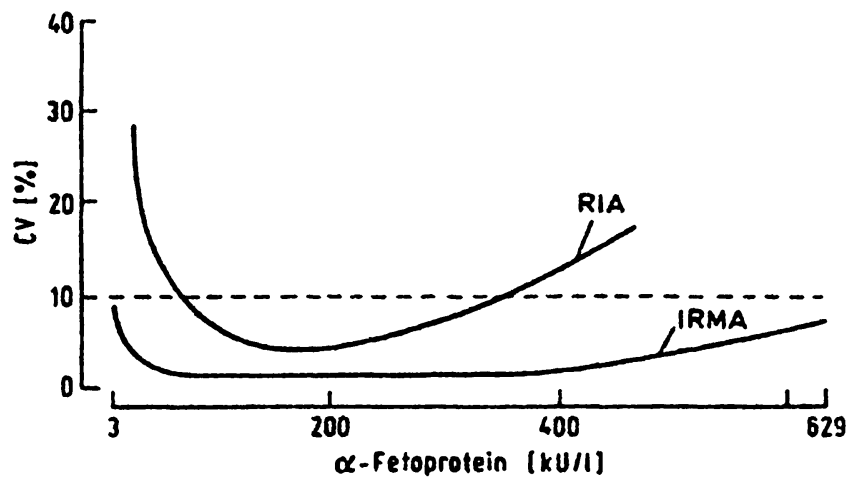

Fig. 1. Intra-assay precision profiles for IRMA and RIA.
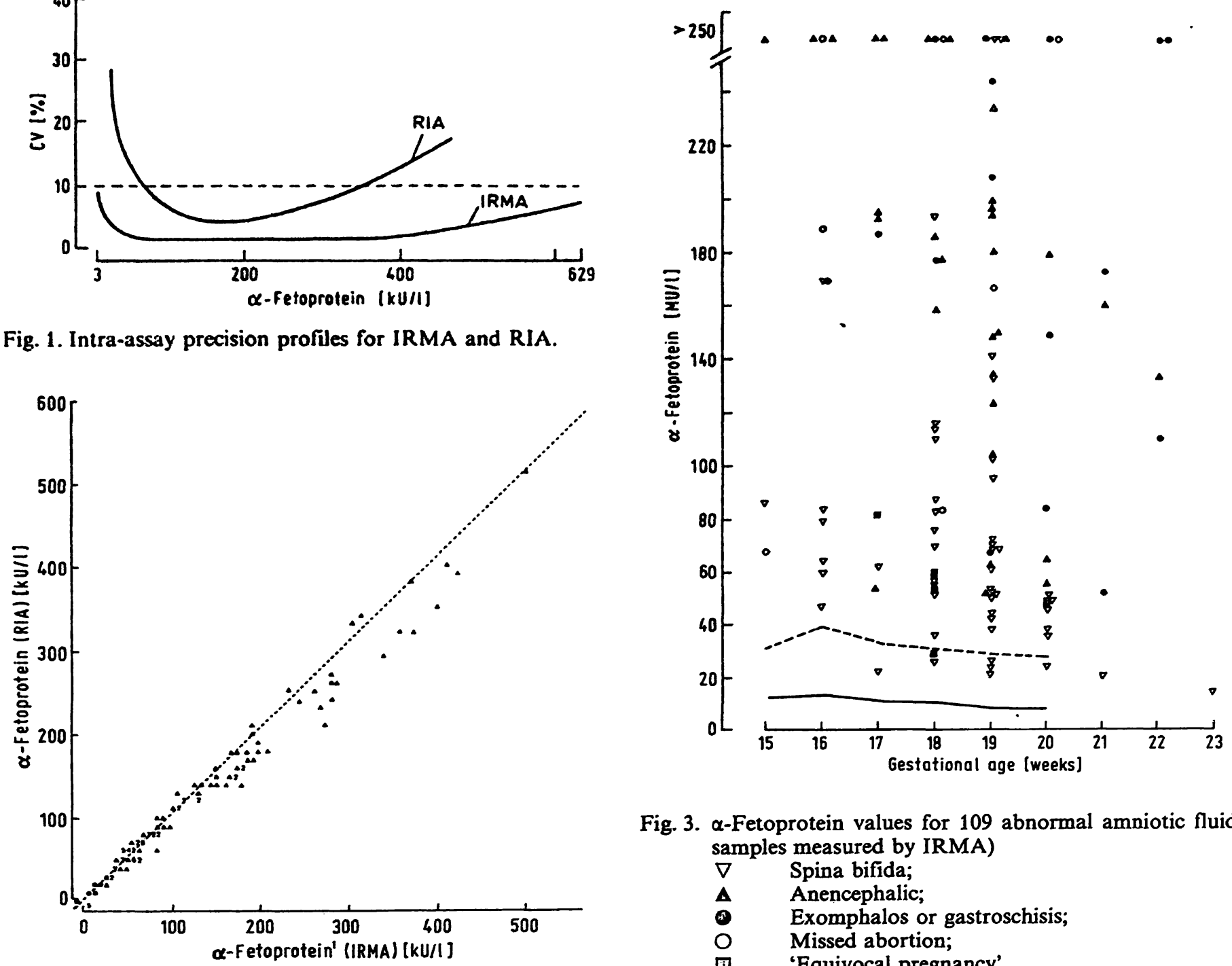

Fig. 3. $\alpha$-Fetoprotein values for 109 abnormal amniotic fluid samples measured by IRMA)

\begin{tabular}{ll}
$\nabla$ & Spina bifida; \\
$\Delta$ & Anencephalic; \\
Ex & Exomphalos or gastroschisis; \\
0 & Missed abortion; \\
(⿴囗十) & 'Equivocal pregnancy' \\
\hline-- Median & Recommended multiple of the median cut-off \\
level (5).
\end{tabular}

Fig. 2. Relationship between $\alpha$-fetoprotein values determined by IRMA and RIA for 231 amniotic fluid samples. (Line indicated represents RIA = IRMA).

Tab. 2. $\alpha$-Fetoportein concentrations of $\mathbf{1 1 6}$ amniotic fluids from normal pregnancies as measured by IRMA.

\begin{tabular}{lllll}
\hline $\begin{array}{l}\text { Gestational age } \\
\text { (weeks) }\end{array}$ & Number of samples & $\begin{array}{l}\text { Range of } \alpha \text {-fetoprotein } \\
\text { values (MU/1) }\end{array}$ & $\begin{array}{l}\text { Median } \alpha \text {-fetoprotein } \\
\text { concentration (MU/1) }\end{array}$ & $\begin{array}{l}\text { Recommended MOM } \\
\text { cut-off level (5) } \\
\text { of } \alpha \text {-fetoprotein (MU/l) }\end{array}$ \\
\hline 15 & 13 & $7.0-18.2$ & 12.6 & 31.4 \\
16 & 25 & $8.3-19.4$ & 13.2 & 39.6 \\
17 & 25 & $6.2-20.2$ & 11.2 & 33.7 \\
18 & 25 & $5.4-22.7$ & 10.4 & 29.0 \\
19 & 20 & $4.3-12.6$ & 8.3 & 28.6 \\
20 & 8 & $5.1-15.4$ & 8.2 & \\
\hline
\end{tabular}


These test outcomes based on the IRMA exactly agreed with the classification given by the reference RIA technique. The amniotic fluid $\alpha$-fetoprotein concentration of 46 of the $52(88.5 \%)$ cases of open spina bifida (gestational age 15-20 weeks) was also greater than the respective multiple of the median cut off levels using the IRMA assay. The remaining 6 cases of open spina bifida had $\alpha$-fetoprotein values by IRMA which fell below the multiple of the median cut off (false negative results). These same 6 cases were similarly misclassified using the RIA technique. Finally, in the further 6 samples from 'equivocal pregnancies' in which the outcome was in each case a normal infant, the $\alpha$-fetoprotein level by IRMA was borderline or elevated, again in accordance with the results of the routine RIA.

\section{Discussion}

Using amniotic fluid samples collected as part of a regional screening service, $\alpha$-fetoprotein values determined by a new, commercially available IRMA were in excellent agreement $(r=0.992)$ with those determined using the RIA in routine use. However, it was noted that agreement between the two methods was less close at higher levels of $\alpha$-fetoprotein ( $>200$ $\mathrm{kU} / \mathrm{l})$, with an apparent positive bias towards the IRMA at these elevated concentrations.

Although this divergence did not affect the clinical utility of either assay, which was excellent in both cases, it is of interest to consider its possible origin more fully. Examination of the intra-assay precision profiles of the RIA and IRMA (fig. 1) reveals that the working range of the IRMA is considerably wider than that of the RIA. This wide working range, a general feature of IRMAs noted 'by others (e. g. l. c. (6)), indicates that at high $\alpha$-fetoprotein concentrations the analytical precision of the IRMA is markedly greater than that of the RIA. Thus the observed divergence of $\alpha$-fetoprotein results at the high extreme may, at least in part, be attributable to the relative imprecision of the RIA.

The ability to measure, using an IRMA, both low and high $\alpha$-fetoprotein concentrations with similar precision and accuracy may be important and desirable, especially in view of recent interest in the association between low maternal serum and amniotic fluid $\alpha$-fetoprotein and Down's syndrome (7).

In summary, the IRMA proved to be a practical, robust and convenient assay for the determination of amniotic fluid $\alpha$-fetoprotein in a routine laboratory. Though the diagnostic performance of both the IRMA and the RIA was identical, in our opinion the IRMA displayed a number of analytical advantages - noteably an extended working range, providing greater confidence at elevated $\alpha$-fetoprotein values. Furthermore, the IRMA's relatively short incubation time ( $2 \mathrm{~h}$ versus $18 \mathrm{~h}+$ for the RIA) allows for the convenience of within-day turnaround of laboratory results.

\section{References}

1. Wright, J. F. \& Hunter, W. M. (1983) 'The sucrose layering separation: A non-centrifugation system'. In: Immunoassays for Clinical Chemistry (Hunter, W. M. \& Corrie, J. E. T., eds.) Edinburgh: Churchill Livingstone.

2. (1979) Equivalence between international units and mass units of $\alpha$-foetoprotein. Report of a collaborative study. Clin. Chim. Acta 96, 59-65.

3. Chubb, I. W., Pilowsky, P. M., Springwell, H. J. \& Pollard, A. C. (1979) Lancet $I, 688-690$.

4. Smith, A. O., Wald, N. J., Cuckle, H. S., Stirrat, G. M., Bobrow, M. \& Lagercrantz, H. (1979) Lancet $I, 685-688$.

5. (1979) “Amniotic fluid alphafetoprotein measurement in antenatal diagnosis of anencephaly and open spina bifida in early pregnancy". Second report of the UK Collaborative Study on alphafetoprotein in relation to neural tube defects. Lancet $I I, 651-661$.

6. Hunter, W. M., Bennie, J. G., Budd, P. S., van Heyningen, V., James, K., Micklem, R. L. \& Scott, A. (1983) "Immunoradiometric assays using monoclonal antibodies". In: Immunoassays for Clinical Chemistry (Hunter, W. M. \& Corrie, J. E. T., eds.) pp. $531-544$. Edinburgh: Churchill Livingstone.

7. Editorial (1985) "Low maternal serum alpha fetoprotein and Down's syndrome". Lancet $I, 252-260$.

E. J. Coombes
Dept. of Chemical Pathology
Salisbury General Infirmary
Salisbury
Wiltshire SP2 7SX
United Kingdom

E. J. Coombes

Salisbury

Wiltşhire SP2 7SX

United Kingdom 